\title{
Capacity Requirements of Accounting Professional and the Innovation of Training Mode
}

\author{
Ping $\mathrm{Du}^{1, \mathrm{a}}$, Jingwen $\mathrm{Li}^{2, \mathrm{~b}}$ \\ ${ }^{1}$ Department of Management, Dalian Jiaotong University, Dalian, 116028, China \\ ${ }^{2}$ Department of Management, Dalian Jiaotong University, Dalian, 116028, China \\ aemail: dupingzt@163.com, bemail: lijingwenangel @163.com
}

Keywords: Accounting Professional; Capacity Requirements; Training Mode

\begin{abstract}
This paper discusses the stakeholders' requirements for accounting talent ability from the characteristics of accounting. We analyzes the existing gap between training mode and ability needs of applied undergraduate accounting personnel .Using the related research at home and abroad for reference, we construct a new accounting talents training mode based on the capacity needs, which including the reconstruction of accounting course system, the innovation of teaching model and improvement of teaching methods.
\end{abstract}

\section{Introduction}

With the increasingly complex economic environment, the changing rules of market operation and the rapid development of economic globalization, the accounting environment is changing and put forward higher request for the ability and quality of accounting personnel. The demand for accounting professional who have stronger ability to adapt will be stronger in future society. The admittance mechanism of accounting talent market let the training of applied undergraduate accounting consider the stakeholders' demand for talent ability. The cultivation of high-quality accounting personnel mainly depends on the innovation of accounting education. However, based on the demand of talent training quality improvement, though the reform is proceeding constantly, there is still a certain distance to the inherent requirement of accounting professional. The main problem of accounting training mode has not been solved fundamentally. Accounting personnel quality and work quality depends largely on accounting education and the universities shoulders the important task of training applied undergraduate accounting professional. Considering the related research at home and abroad, building a new training mode based on the capacity requirement of accounting talents has become an urgent problem to study.

\section{Job Characteristics and Capacity Needs of Accounting}

Job characteristics of accounting: As a profession, the main features of accounting can be summarized as two aspects of professional competence and ethics. Professional competence refers to the technicality and comprehensive of accounting profession. Technicality is a main characteristic of accounting profession which is different from other types of professions, including the transformation of accounting language and the generation of accounting information. As a language of business, accounting based on the principles of accounting transfers scattered information into systemic and integrated information to meet the various needs of the user. Ethics belongs to the ideological characteristics and it is the basic moral standards should be followed and values of practitioners should be displayed .Good professional ethics is the soul of the accounting profession and the foundation of high quality accounting information [1].

The environment of accounting profession changes quickly, such as economic globalization, technological innovation that makes the accounting business more complex, so the traditional function changes constantly. These variations of macro and micro environment also change the requirement of accounting profession, which need the accounting professional to have larger capacity to adapt to the changes in the environment.

Capacity needs of accounting based on stakeholders: From the accounting professional 
characteristics above, we can see the requirements for practitioners. The scope of accounting profession service is very broad and we should not only consider the demand of the accounting profession but also the needs of other stakeholders (such as industrial community, accounting educatees, accountants and so on).

Relevant institutions of home and abroad have descript the capacity needs of accounting professional, such as AECC published "the Objectives of Accounting Education: Public Announcement No. 2" in 1990 that thinks we should view the role of accounting from a broader perspective. The International Accounting Education Standards Committee of International Joint Accountant (IPAC) described clearly the accounting personnel's ability in five aspects from the knowledge skills, technical skills, personal skills and interpersonal skills in 2003. According to the research of Yang Zheng, etc. (2012), there isn't a significant difference between professional ethics and professional ability on the importance of cognition of different stakeholders [2]. In September 2010, the Ministry of Finance released "the accounting industry medium and long-term talent development plan (2010-2020)" and pointed out that all enterprises and institutions should focus on training lots of senior accounting talents who have the international ability and can solve the complex economic problems [3].

This paper argues that the capacity of accounting personnel should mainly include three aspects: professional ethics, professional knowledge and professional skills based on the accounting professional characteristics and the needs of stakeholders.

Professional ethics: The accounting professional ethics is the sum of the basic moral consciousness and norms the practitioners should established in accounting work. It goes through all areas and the whole process of the accounting work, guides and restricts the accounting behavior. Professional ethics is a kind of non-mandatory norms and a unification of heteronomy and self-discipline that relies mainly on the social public opinion and moral power to maintain.

Professional knowledge: Accounting personnel are mainly engaged in the accounting and financial work in for-profit and non-profit organizations, and their professional knowledge structure is mainly to meet their needs. Another important character of accounting business is comprehensive. A certain depth and breadth of accounting knowledge are required in the knowledge structure. So other economic management knowledge is also included in the system of knowledge.

Professional skills: Professional knowledge is the foundation and what's more important is the ability to apply this knowledge in the complex work environment. Accounting is the profession that depends on professional judgment under the guide of criterion, so different judgments have different economic consequences. Therefore, open and comprehensive thinking ability, interpersonal skills, communication skills, strong ability of professional judgment and decision-making ability are also need to require for the accounting personnel.

\section{The Disjunction between Cultivation and Capacity Demand of Accounting Professional}

The popularization of higher education develops towards professionalism and popularity but the cultivation of accounting undergraduate talents are under the control of the requirements of the industry and the accounting profession rather than universities. The mechanism of accounting market let the training of accounting consider the stakeholders' demand .Currently, lack of effective communication between institutions and stakeholders exists. That situation is mainly manifested in the following aspects:

Ignoring the elevating of professional ethics and comprehensive quality: Applied undergraduate accounting education focuses too much on the professional knowledge and the cultivation of professional ability while ignores the professional skills and professional values. With the economic globalization, accounting students is facing diversified job in the future and the social demand for accounting talents has already not only limited to the accounting knowledge but higher request to grasp the connotation of economic transaction. Neglecting the cultivation of personnel professional ethics, personality cultivation and other kinds of abilities is one of the problems universally existing in accounting education.

Lack of theoretical analysis and being weak in practice teaching: Our teaching of accounting emphasizes on various accounting norms and has the tendency to exclude professional theory knowledge. So this guiding must dismember the systematicness of the generally accepted 
accounting principles. As a result the students just learn but don't know the why and they cannot understand the whole accounting principles. When they face the complex economic transaction they will get helpless or misuse the accounting principles [4]. Accounting education focuses on the teaching of professional knowledge and the professional ability while ignores the role of practice education, that lead to many problems such as the lack understanding of practical experience, the disconnection of theoretical research and accounting practice.

In the process of undergraduate accounting education practice, schools have set up accounting simulation laboratory to operating accounting professional practice but the school still has some problems (boring content of teaching, narrow scope and single form). There is rarely collaboration in the experiments and a student tends to simulate a variety of roles from beginning to end which is not conducive to cultivate the students' communication, team cooperation and management ability.

Off-campus internships are typically finding internship units by students or organizing students to practice in off-campus internship by schools. Usually the enterprise's financial information is secret and generally a enterprise is difficult to accept a lot of internship students due to the particularity of accounting job. As a result, most of the colleges and universities lack the stable off-campus practice base. It's difficult for schools to manage because the internship condition is hard to confirm and the units is scattered when students find units by themselves. Internal accounting experiment is lack of comprehensive and external accounting practice becomes a mere formality, so the expected effect can't be reached.

The disconnect of course system, teaching mode and the training of accounting professional core ability: Currently universities' accounting professional training scheme are generally divided into public basic courses, general quality course, foundation courses, professional courses, professional elective courses and practice courses, etc. This system emphasizes on the degree of specialization not the generality of knowledge structure. The students neglect the basic courses such as economics and management, etc. So it is difficult for them to understand accounting from the perspectives of economics and management. The reform is proceeding but it's just the local adjustment of curriculum system, therefore the construction of curriculum system can't be closely linked with the internal requirement of cultivating. This rule teaching (pre-formulation of curriculum system) goes against the cultivation of modern accounting talents. In the era of knowledge economy, knowledge updates more rapidly and the term is shortening. The Extending of accounting function requires college accounting classes to reflect rapidly. With the convergence even the equivalent of accounting, our university accounting course system has made significant progress but the related courses are too old to face the business processes management risk.

In the traditional accounting teaching mode that teachers are the center and they pay attention to the textbook knowledge but ignore the training of students' professional judgment ability. It is difficult to adapt to the function of organizational decision under the condition of information technology. Formal style teaching is a completely passive learning and enclosed teaching mode that the teacher assumed an idealized scenario to explain accounting rules. The teachers and students are lack of communication and the necessary information communication. The students master the knowledge but could not cope with the complex real world. So this teaching mode can't fully arouse the subjective initiative of students, neither excavate the potential of students, so it's difficult to achieve the transformation of "knowledge - ability".

\section{Innovation of Training Mode Based on the Capacity Demand}

Reconstructing the accounting course system: Based on the accounting personnel's capacity demand, curriculum system should provide necessary knowledge and professional skills. We can learn from the experience of international first-class business school such as the course modularization of Wharton business school. They divide the undergraduate accounting course into 37 categories (economics and mathematics, writing ability, business base, social environment, organizational environment, general education, business scope, etc.) according to the curriculum knowledge. They clear each module's contribution to the complete ability framework to enhance the overall structure force of students' knowledge. In order to ensure the knowledge system, they let 
professional teachers be academic advisers to provide suggestions of college learning plans and course selection for students [5].

Set modules based on the ability demand, clear each module's contribution to the ability frame, correctly handle the relationship between theory and practice and perfect the curriculum system settings. Pay attention to improving students' comprehensive quality and practical application ability.

Innovating the teaching mode: As the employment pressure increases, the boom of professional qualification exam has entered the campus. Applied undergraduate accounting education should combine CPA courses with undergraduate course education, that let the student get the bachelor degree of accounting at the same time, also obtain accounting qualifications and pass the professional qualification certificate of accounting.

Colleges should communicate and cooperate actively with industrial community and accounting profession, involve them in accounting teaching mode innovation, and exert their advantages and practical experience to participate in accounting education. Strengthen the cooperation of school and enterprises, establish outside accounting training base, encourage students to go out of school and train their ability to solve practical accounting issues. Regularly invite celebrities to give lecture, so that the students can grasp the latest industry information. Promote the cooperation of accounting education, profession and industry community, build the new mode of accounting education and improve the quality of accounting education.

Improving the teaching methods: Teacher's teaching still should be the most important teaching method but we should change the past method that students are passively accepted. Teachers should turn the unidirectional teaching into the bilateral teaching, promote case teaching, scene simulation teaching, high-level lectures, interactive teaching and inquiry teaching to cultivate the students' comprehensive ability and reinforce their ability to solve current problems. Let students use theory as a tool to solve the actual problems, at the same time extend students' knowledge and change the passive learning into active learning.

Combine accounting theory teaching with practice teaching. Construct scientific accounting practice teaching system: there're a lot of cognitive projects but few comprehensive projects in simulated experiment teaching. We can improve the simulation of practice in the form of group division of labor in innovating practice teaching mode. Simulate the whole or a single process of accounting business process. A large number of "role" simulation training, can make students quickly involve into the role and improve students' ability of flexible reaction and collaboration.

\section{References}

[1] Sun Chao-xia, Wang Hui. Research on the Training Goal of Accounting Professional based on the Ability Structure, [J]. Journal of Institute of Hefei, 2011(11) 97-100

[2] Yang Zheng, Yin Jun-ming, Song Ya-qin. Accounting Talent Demand and the Undergraduate Accounting Education Reform: the Investigation and Analysis of the Stakeholders, [J]. Accounting Research, 2012 (1) 15-17

[3] Liu Yu-ting. Popularize XBRL and Develop Accounting Information, [J]. Accounting Research, 2012 (11) 3-9

[4] Gao Ke-zhi, Wang Hui. Accounting Professional Core Ability and its Training Path Research, [J]. Journal of Anhui Agricultural University (social sciences) 2011 (3) 104-108

[5] Yi Xuan, Liu Dong-dong. Environmental Changes, Demand Changes and College Accounting Education Reform, [J]. Journal of Hunan University of Science and Technology, 2012 (4) 156-160 